\title{
Language Anxiety in Focus: The Case of Filipino Undergraduate Teacher Education Learners
}

\author{
Rhodora R. Jugo \\ Graduate School, Nueva Ecija University of Science and Technology, Cabanatuan City 3100, Nueva Ecija, Philippines \\ Correspondence should be addressed to Rhodora R. Jugo; rhodora.jugo@neust.edu.ph
}

Received 31 January 2020; Revised 30 May 2020; Accepted 3 June 2020; Published 29 June 2020

Academic Editor: Gwo-Jen Hwang

Copyright (c) 2020 Rhodora R. Jugo. This is an open access article distributed under the Creative Commons Attribution License, which permits unrestricted use, distribution, and reproduction in any medium, provided the original work is properly cited.

\begin{abstract}
This study has focused on determining the level, sources, and causes of foreign language anxiety of students taking up teacher education courses in the Philippines and how language anxiety affects the English proficiency of the respondents and their language learning. A total of 242 learners from a Philippine-based learning institution answered an English proficiency exam (EPE) and a questionnaire comprising two parts: a 30-item English Language Anxiety Scale (ELAS) and a set of questions on causes of anxiety and effects on language learning. Means, standard deviation, frequency, and percentage were calculated and used to characterize language anxiety level, sources, and causes. Correlation and regression analyses of the language anxiety variables and English proficiency of the respondents were then conducted. Follow-up interviews were also done for selected respondents in order to understand the nature and mechanism of the investigated relationships. The results confirmed that the speaking activity, error correction, and communicating with English speakers are sources of high anxiety of the Filipino learners, while the writing activity, negative self-perception, and noncomprehension are sources of moderate anxiety. All of the sources of anxiety were shown to have a significant negative relationship with second language anxiety, and simple regression analysis revealed that foreign language anxiety is a significant predictor of English proficiency. However, further analysis of the specific sources of anxiety using multiple regression analysis identified speaking activities anxiety as the only significant predictor of English proficiency.
\end{abstract}

\section{Introduction}

English has long since emerged and been recognized and established worldwide not only as the most common language but also as the most important one. It plays a significant role in the academic and professional lives of individuals [1-3] and serves as the lingua franca of international business sectors driving economic growth and international development $[4,5]$, directly and indirectly, affecting operations and transactions. Thus, the English language impacts both a country's economy and its educational system.

While its official national language is Filipino, English is considered the second language for the Philippines. English is also the nonexclusive language of science and technology [6], which aims for the competence of learners in both
Filipino and English at the national level. Teaching English as the medium of instruction is a crucial component of the Philippine school system. The proliferation of its usage is so extensive that it is ingrained in almost every aspect of communication. In fact, one of the country's identified strengths, which helped drive its economy and made the country the top provider of voice outsourcing, is the English proficiency of Filipinos [4].

However, although the Philippines is still one of the preferred countries for foreign learners of English due to the affordability and quality of its English as Second Language Programs being offered, there is a worrying trend of decreasing English competence of teachers and learners. The English proficiency of the Filipino workforce has declined [7], which might be attributed to Filipino graduates having only English proficiency at the basic working proficiency level. 
Numerous and varied studies have been conducted to determine the factors that affect English proficiency, particularly the language learning of nonnative English users. Evidence has shown that language anxiety is one of the strongest predictors of language learning success and that it has incapacitating effects on the language learner $[8,9]$. Whereas facilitating anxiety produces positive effects on the learners' performance, too much anxiety may cause poor performance [10].

Horwitz et al. [11] described language anxiety as a situation-specific anxiety construct, which is mostly independent of the other types of anxiety and is characterized as "high feelings of self-consciousness and fear of making mistakes and a desire to be perfect when speaking," while Gardner and MacIntyre [12] described language anxiety as the apprehension that occurs when a language student learns a second or foreign language. There are contributing factors to language anxiety of learners, such as participating in speaking activities, inability to understand the lessons, and evaluation among others, while inhibiting factors are peer affiliation or a feeling of communal connectedness, classroom set-up, and teacher's role [13]. Language anxiety can be manifested in the different stages of language learning, the input, processing, and output stages, and describing how anxiety is related to these three stages can provide insights on why second language learners and foreign language learners suffer from linguistic difficulties and mistakes [14].

Although there is sufficient literature about foreign language learning anxiety, there is still a scarcity of available and published written materials investigating the status of foreign language learning anxiety in the Philippines. Thus, intending to address this problem, this study investigated the attributions about the English language anxiety of Filipino students enrolled in teacher education courses and how language anxiety affects their English proficiency and their language learning. Specifically, the study sought to address the following issues.

(1) What are the sources of language anxiety of Filipino teacher education learners?

(2) What are the causes of the respondents' language anxiety?

(3) How may the English proficiency of the respondents be described?

(4) Is there a significant relationship between the language anxiety of the respondents and their English proficiency?

(5) How does language anxiety affect the second language learning of the respondents?

(6) How may the effects of language anxiety on the second language learning of the respondents be described?

\section{Materials and Methods}

2.1. Research Design. This research study is descriptive and focuses on the identification of the sources and causes of second language anxiety and analysis of how language anxiety affects language learning. Descriptive statistics were also applied utilizing mean for the five-point Likert scale aspect of the questionnaire and frequency, standard deviation, and percentage for the other variables. Further, a test of correlation and regression analyses was also done to determine the relationship between second language anxiety and English proficiency.

2.2. Participants. Respondents in this study were 242 (166 female and 76 male) first-year college students taking up teacher education courses in the Philippines and are registered in English language courses. With an average age of 16.57 years $(\mathrm{SD}=1.16)$, the respondents came from various teacher education courses including Bachelor of Secondary Education (BSE), Bachelor of Science in Industrial Education (BSIE), and Bachelor of Elementary Education (BEED).

2.3. Instruments. The researcher employed two kinds of data gathering tool, an English proficiency exam (EPE), which is a test that intends to measure the English proficiency level of Filipino students enrolled in teacher education courses, and a questionnaire comprising two parts: a 30-item English Language Anxiety Scale (ELAS) and a set of questions on causes of anxiety and effects on language learning. A series of interviews were also done to validate and clarify the responses of the learners for the ELAS.

The ELAS is a 30-item Likert-type questionnaire, which uncovers the anxiety level of the examinee. It is a researchermade questionnaire inspired by Clement, Gardner, and Smythe (1977). The researcher contextualized the sources of language anxiety based on the needs and characteristics of Filipino learners. The premise is that Filipino learners' language anxiety is not limited to second language speaking activities but also commonly stems from other English classroom activities, mainly writing, error corrections, communicating with native English speakers, negative selfperception, and noncomprehension. These were the basis of the components of the ELAS. It was developed through the guidance of language experts. The trial form of the questionnaire initially had 60 items, subjected to the scrutiny and content analysis of five educational experts in the field of psychology and educational measurement. In the evaluation process, only 40 items qualified as measures of anxiety, 10 of which were for revisions and rephrasing and 10, for deletions, as these were only redundancies. The test-retest method was used to determine the reliability of the instrument, and the obtained $r$ was .78, which means that both forms are not only genuinely parallel but also stable measures of what it intends to measure, in short, reliable. Any of the two forms can be used in place of the other.

The second part of the questionnaire is made up of openended response questions. The first question is about what the respondents believe are the reasons other people experience language anxiety, which was intended to generate the probable attributions of anxiety. The question was designed to reflect what the learners observe in others rather than what they experience to ensure the respondents will provide a comprehensive response. The second question deals with situations or events inside their English classroom that caused them anxiety. 
2.4. Procedure. Before the conduct of the study, the researcher sought the approval of the University Vice-President for Academic Affairs and the University Research Technical Committee. Data were collected for 12 weeks in a semester. Informed consent was obtained from the participants, and the questionnaire was administered, and informal interviews were conducted according to the established university research ethical guidelines.

2.5. Data Analysis. The ELAS is answered on a five-point Likert scale: 1 (not at all), 2 (rarely), 3 (sometimes), 4 (often), and 5 (always). Meanwhile, the interpretation of ELAS responses, on the other hand, is guided by the local norm in Table 1, while the regional English proficiency exam scores can be analyzed according to the categories in Table 2. The interpretation of responses is only appropriate for the result of ELAS and not for the English proficiency exam since this is based on scores and not weighted mean. The regional English proficiency exam scores can be analyzed according to the categories in Table 2.

The information and data collected were then subjected to analysis and evaluation by using appropriate statistical tools, including SPSS. Weighted mean and standard deviation were used to describe the respondents' anxiety level, while frequency, percentage, and standard deviation were used to characterize the causes of anxiety and English proficiency. Pearson product-moment correlation was used to examine the relationship between language anxiety and English proficiency. Regression statistics were also done to determine if a significant association exists between language anxiety and English proficiency. A simple regression analysis between English language anxiety and English proficiency and multiple regression analysis between sources of anxiety and English proficiency were conducted.

\section{Results and Discussion}

3.1. Sources of English Language Anxiety of Undergraduate Filipino Teacher Education Learners. The overall level of language anxiety of the respondents is moderate $(M=3.40$, $\mathrm{SD}=0.36$ ), as shown in Table 3 . As can be seen, speaking activity was identified as the primary source of language anxiety $(M=3.64, \mathrm{SD}=0.60)$, followed by error correction $(M=3.50, \mathrm{SD}=0.49)$ and communicating with English speakers $(M=3.49, \mathrm{SD}=0.42)$. These three were all rated by Filipino learners as sources of high levels of anxiety. On the other hand, writing activity $(M=3.23, \mathrm{SD}=0.32)$, negative self-perception $(M=3.28, \mathrm{SD}=0.36)$, and noncomprehension $(M=3.26, \mathrm{SD}=0.46)$ were all identified as sources of moderate levels of anxiety.

The results imply that anxious students felt a deep selfconsciousness when asked to speak using the English language in the presence of other people. They worried much about the errors they might be committing, and they did not like being laughed at or making a fool of themselves in public. The result was evident in English classes where the students tried to avoid activities like recitation, speech delivery, and the like since speaking needed to be spontaneous,
TABLE 1: English language anxiety rating scale.

\begin{tabular}{lc}
\hline Mean & Interpretation \\
\hline $4.31-5.0$ & Very high anxiety \\
$3.51-4.30$ & High anxiety \\
$2.71-3.50$ & Moderate anxiety \\
$1.81-2.70$ & Low anxiety \\
Below 1.8 & Very low anxiety \\
\hline
\end{tabular}

TABLE 2: Regional English proficiency exam score categories.

\begin{tabular}{lc}
\hline Scores & Description \\
\hline 69.5 and above & Outstanding \\
$59.6-69.4$ & Very high \\
$49.2-59.5$ & High \\
$38.8-49.1$ & Average \\
$28.4-38.7$ & Low \\
$18.0-28.3$ & Very low \\
Below 18 & Poor \\
\hline
\end{tabular}

TABLE 3: Sources of language anxiety.

\begin{tabular}{lccc}
\hline Indicators & $\mathrm{M}$ & $\mathrm{SD}$ & Interpretation \\
\hline Speaking activity & 3.64 & 0.60 & High \\
Writing activity & 3.23 & 0.32 & Moderate \\
Error correction & 3.5 & 0.49 & High \\
Communicating with & 3.49 & 0.42 & High \\
English speakers & 3.28 & 0.36 & Moderate \\
Negative self-perception & 3.26 & 0.46 & Moderate \\
Noncomprehension & 3.40 & & Moderate \\
Overall & & &
\end{tabular}

and learners find it embarrassing on their part when the entire class hears every single mistake they committed. Of the sources of anxiety, error correction ranked second, which is attributed to the fact that students do not want to be criticized and corrected in front of the whole class. Even in writing activities, students were embarrassed and even afraid to see their outputs evaluated as having many errors and appearing with too many red marks. Red marks are usually associated by Filipino learners with negative feelings because these are evidence of error corrections, and thus, poor performance.

Analysis of these specific sources of anxiety can further explain what the learners feel towards foreign language learning. Table 4 presents the indicators of foreign language speaking activity anxiety, which is the anxiety experienced by learners when talking with or speaking in front of their classmates and teachers using the target language, English. These speaking activities are all high sources of foreign language anxiety for the learners. The tendency to be at a loss for words was the primary source of speaking anxiety $(M=3.77)$, followed by quivering at the thought of speaking in English before the class $(M=3.71)$.

Filipino learners' anxious thoughts on speaking keep them focused on their learning difficulties and, in turn, might affect their learning process. The distraction caused by negative thoughts keeps them from focusing on the task at hand, causing them to suffer from an inability to process, continue, or complete and even express a train of thought. 
TABLE 4: Speaking activity anxiety of the respondents.

\begin{tabular}{lcc}
\hline Indicators & Mean & Interpretation \\
\hline I panic when I have to speak in English. & 3.64 & High \\
I tend to be at a loss for words whenever & 3.77 & High \\
I speak in English. & 3.64 \\
$\begin{array}{l}\text { I feel self-conscious whenever I speak in } \\
\text { English. }\end{array}$ & 3.44 \\
$\begin{array}{l}\text { I tremble when I am to be called on to } \\
\text { recite in an English class. }\end{array}$ & 3.71 \\
$\begin{array}{l}\text { I quiver at the thought of speaking in } \\
\text { English before the class. }\end{array}$
\end{tabular}

This finding supports the study of Yalçın and İnceçay [15], which showed that anxious foreign language Turkish students identify speaking in the target language as the most frightening language skill and that they feel stressed and even start to "freeze" when they have to act out a role-play or deliver a speech. Similarly, in a study by Liu and Jackson [8], Chinese learners of English as a foreign language displayed an unwillingness to communicate and revealed that most of their participants were willing to participate in interpersonal conversations. However, they did not like the risk of using or speaking in English in class. "Speaking in the foreign language is often cited by students as their most anxiety-producing experience" and also "difficulty in speaking in class is probably the most frequently cited concern of the anxious foreign language students" [11, 16].

If speaking activities cause high anxiety levels in Filipino foreign language learners, writing activities seem to cause only a moderate level of anxiety, as shown in Table 5. It is interesting to note that the learners' apprehension of writing activities using English causes high anxiety $(M=3.96)$, but all the other indicators only incite a moderate or low level of anxiety. The learners become moderately anxious because they tend to get upset when required to write a composition in English and because they are not confident of their writing skills in English $(M=2.5)$. The fear of creating an English work that is of poor quality $(M=3.21)$ also causes moderate anxiety. However, nervousness in essay-writing during tests is only a low source of anxiety $(M=2.46)$. This result is probably because essay-writing in exams requires a shorter answer compared with writing an English work, which entails a longer work of using English, thus causing more apprehension.

Speaking anxiety and writing anxiety are language-skill specific anxieties that are different from a general classroomtype of anxiety, meaning some students may be prone to suffer from anxiety in any second language class. In contrast, some may be particularly susceptible to anxiety in a situation in which a particular language skill is emphasized. Filipino learners seem to be more susceptible to speaking anxieties than writing anxieties. The difference might stem from the fact that speaking entails a high exposure compared with writing activities. When Filipino learners are asked to speak in front of the class, they feel more vulnerable because of the fear that their foreign language weaknesses will be exposed to their teacher and classmates, causing them to lose their self-esteem.
This further supports the concept that the second language classroom anxiety and language-skill specific anxieties are two relatively independent constructs, each having its unique characteristics. Still, they share commonalities such as a negative effect towards certain aspects of communication, avoidance of certain kinds of social exchanges, and fear of being evaluated.

Error correction is also a source of high anxiety $(M=3.5)$, as shown in Table 6. Their classmate's criticisms of their written works are at the forefront of the Filipino learner's high anxiety $(M=3.71)$, followed by being corrected while speaking in English $(M=3.57)$. Worrying about corrections in their English composition $(M=3.57)$ and seeing red marks in their paper $(M=3.43)$ are also causes of high anxiety for the Filipino foreign language learners. The fear that their written work would be deemed as funny or absurd by their teacher and classmates is a source of moderate anxiety $(M=3.24)$.

The fear of making mistakes and being corrected or negatively evaluated is a significant source of anxiety for the Filipino learners. It can be explained as the feeling commonly associated with the evaluation of performance when being corrected or a learner's anxiety as caused by corrective observations when he or she uses the target language, which in this case is English. Like other foreign language students, Filipino foreign language learners usually do not want to be criticized and corrected in front of the whole class. In the study conducted by Yahya [17], fear of error correction or negative evaluation was identified as the most significant cause of foreign language anxiety, while the study of Ok and Ustaci [18] on Turkish EFL learners also showed that the students preferred not to be corrected by their teachers when they made a mistake while speaking because they believed the corrections made by their teacher were a source of anxiety.

Table 7 shows that another source of high anxiety of Filipino learners is communicating with English speakers. Specifically, the learners are afraid of talking to a native English speaker $(M=3.92)$ and are very self-conscious $(M=3.63)$ when speaking in English in front of an audience of native English speakers. The feeling of nervousness $(M=3.4)$, fear of sounding absurd $(M=3.27)$, and fear of writing to a native English user $(M=3.21)$ are all sources of moderate anxiety.

Even in the indicators of anxiety due to communicating with native English users, speaking-related activities are still 
TABLE 5: Writing activity anxiety of the respondents.

\begin{tabular}{lcc}
\hline Indicators & Mean & Interpretation \\
\hline I am afraid that my English works would look absurd. & 3.21 & Moderate \\
I am afraid of activities requiring the use of English. & 3.96 & High \\
I get upset when the class is required to write a composition in English. & 3.25 & Moderate \\
I am not confident in my writing skills in English. & 3.25 & Moderate \\
I get nervous when the test requires essay writing in English. & 2.46 & Low \\
General weighted mean & 3.23 & Moderate \\
\hline
\end{tabular}

TABLE 6: Error correction anxiety of the respondents.

\begin{tabular}{lcc}
\hline Indicators & Mean & Interpretation \\
\hline I am afraid of being corrected while I am speaking in English. & 3.57 & High \\
I worry that my English composition will be criticized & 3.57 & High \\
I feel embarrassed about seeing red marks in my English compositions. & 3.43 & High \\
I am afraid that my classmates will criticize my written works in English. & 3.71 & High \\
I am anxious that my English composition would turn out funny. & 3.24 & Moderate \\
General weighted mean & 3.5 & High \\
\hline
\end{tabular}

TABLE 7: Communicating with English speakers.

\begin{tabular}{lcc}
\hline Indicators & Mean & Interpretation \\
\hline I am afraid I will sound absurd when speaking with a foreigner. & 3.27 & Moderate \\
I am afraid of talking to a native English user. & 3.92 & High \\
I am afraid of writing to a native English user. & 3.21 & Moderate \\
I get nervous just at the thought of talking to a foreigner. & 3.4 & Moderate \\
I feel very self-conscious about speaking the English language in front of native speakers. & 3.63 & High \\
General weighted mean & 3.49 & High \\
\hline
\end{tabular}

the causes of the high anxiety in Filipino learners. The learners reported that when they are not able to understand all the words that the English user is saying, they are afraid they might respond incorrectly. This leads to anxiety and fear of "losing face" or being ridiculed by people who are part of the conversation or even other people who hear the conversation, particularly their peers. This affects their selfimage and confidence, thus causing them to avoid speaking or talking to native English users. This might be due to the Filipino learner's perception that since a native English speaker has full command of the English language, their linguistic competence on the use of English cannot compare, causing them anxiety. According to the study of Hashemi [19], involving language anxiety of Iranian learners, the feeling of inferiority and apprehensiveness to communicate with a native English user stems from the learner's lack of confidence in one's linguistic competence.

Generally, negative self-perception is a source of moderate anxiety for Filipino learners, as shown in Table 8. Only the feeling of not doing well in their English class is a source of high anxiety $(M=3.54)$, while the rest of the indicators of negative self-perception are of moderate anxiety. The fear that their classmates will do better than them $(M=3.31)$, fear of failing in their English class $(M=3.21)$, feeling inferior to their classmates $(M=3.19)$, and lack of confidence in their performance in their English class $(M=3.17)$ were rated as sources of moderate anxiety.

Self-confidence affects successful language learning and is also related to foreign language anxiety. A lower self-confidence would mean difficulty in language learning, which might lead to higher language anxiety. Filipino learners who are confident in their ability are generally more motivated to learn and perform better and would partake more in the activities and tasks in their foreign language classroom. However, Filipino learners who have low self-confidence would avoid these activities because they fear that they will not be able to perform as well as their classmates. For example, in their foreign language classroom activities, students who are identified to be proficient in English would be delegated by their classmates to be their representatives and leaders. Also, during recitations, they would avoid answering once a classmate who speaks English proficiently has already spoken since they are anxious that their answer might not be comparable to that of their classmate. Several studies also support the belief that self-confidence is an essential factor for successful language learning. For first-year Japanese students, self-confidence is an essential factor in their foreign language classroom performance [20]. Daley et al. [21] and Casado and Dereshiwsky [22] found the same results examining university students' language learning and language anxiety. According to these studies, self-confidence is the key to language learning.

Noncomprehension is only a source of moderate anxiety for Filipino learners, given that all the indicators only obtained a moderate anxiety rating, as shown in Table 9. The fear of not accurately understanding English materials that they have heard and the feeling of not being able to give the details of the English materials that they read obtained the highest means of 3.37 and 3.36, respectively. 
TABLE 8: Negative self-perception.

\begin{tabular}{lcc}
\hline Indicators & Mean & Interpretation \\
\hline I feel inferior to my classmates as far as English is concerned. & 3.19 & Moderate \\
I am not confident of my performance in my English classes. & 3.17 & Moderate \\
I have a feeling I will not do good in my English classes. & 3.54 & High \\
My classmates do better in English than I do. & 3.31 & Moderate \\
I have a feeling I will fail in my English classes. & 3.21 & Moderate \\
General weighted mean & 3.28 & Moderate \\
\hline
\end{tabular}

TABle 9: Noncomprehension.

\begin{tabular}{lcc}
\hline Indicators & Mean & Interpretation \\
\hline I am afraid I do not really understand the English materials that I read. & 3.21 & Moderate \\
I fear I do not accurately understand English materials that I heard. & 3.37 & Moderate \\
I am afraid I may not understand directions written in English. & 3.14 & Moderate \\
I am afraid of not understanding discussions in English. & 3.24 & Moderate \\
I feel I will not be able to give details of the English material I read. & 3.36 & Moderate \\
General weighted mean & 3.26 & Moderate \\
\hline
\end{tabular}

According to Carrell and Grabe [23], when second language learners read in a foreign language, this increases the difficulties of the reading process. The same holds true to the listening process. As second language learners read or listen, their minds are trying to decode unfamiliar scripts or words and writing systems. Difficulties encountered in processing these may lead to frustration, which in turn might lead to anxiety. Filipino learners, on the other hand, do not perceive noncomprehension as a strong source of their language anxiety, although it is still a source of anxiety. The weaker impact on the learners seems to suggest that Filipino learners are more affected by second language learning activities that have audiences and the possibility of immediate negative feedback.

3.2. Causes of Anxiety of Undergraduate Filipino Teacher Education Learners. It is interesting to note that when the respondents were asked to identify who is responsible for their language anxiety, most of the learners acknowledged themselves as the primary cause of the anxiety that they experience, as shown in Table 10.

When taken in context with the sources of anxiety that obtained a high rating, it is clear that the Filipino learners believe that the anxiousness that individuals feel from speaking using a foreign language, error corrections received during foreign language classes, and communicating with native English speakers is anchored on one's self-perception, particularly on the importance that they place on what they believe others think about them and their perceived linguistic competency.

\subsection{English Proficiency of Undergraduate Filipino Teacher} Education Learners. Table 11 shows that of the 242 respondents, barely one-half obtained an average score (101 or $41.74 \%$ ). Most respondents obtained a low rating (86 or $35.54 \%$ ), and some obtained a very low score (16 or $6.61 \%$ ). Only $28(11.57 \%)$ to $11(4.55 \%)$ respondents scored high to very high. The mean marked score of the respondents is
TABLE 10: Causes of language anxiety.

\begin{tabular}{lcc}
\hline Causes & $f$ & $\%$ \\
\hline Self & 98 & 40.50 \\
Teacher & 29 & 11.98 \\
Activity & 73 & 30.17 \\
Peers/audience/friends & 42 & 17.36 \\
Total & 242 & 100.00 \\
\hline
\end{tabular}

TABLE 11: English proficiency of the undergraduate Filipino teacher education learners.

\begin{tabular}{lccc}
\hline Scores & $f$ & $\%$ & Description \\
\hline $59.6-69.4$ & 11 & 4.55 & Very high \\
$49.2-59.5$ & 28 & 11.57 & High \\
$38.8-49.1$ & 101 & 41.74 & Average \\
$28.4-38.7$ & 86 & 35.54 & Low \\
$18.0-28.3$ & 16 & 6.61 & Very low \\
Total & 242 & 100 & \\
\hline
\end{tabular}

$40.98( \pm \mathrm{SD}=9.32, n=242)$, showing an average performance in the English proficiency exam.

The findings imply that the majority of the respondents in the study have not yet attained the proficiency and English mastery required of them to be effective users of the language and teachers of the subjects taught in English. One explanation for this is that the quality of secondary English preparations of the students lacked the basic skills needed for them to cope with the demands of the tertiary level.

3.4. Relationship of Foreign Language Anxiety to English Proficiency. Pearson's correlation coefficient was computed to establish the relationship between foreign language anxiety and English proficiency (Table 12). A more in-depth correlational analysis between the specific sources of foreign language anxiety and English proficiency was also conducted. 
TABLE 12: Correlation between foreign language anxiety and English proficiency.

\begin{tabular}{lc}
\hline & English proficiency \\
\hline Speaking activity & $-0.675^{* *}$ \\
Writing activity & $-0.482^{* *}$ \\
Error correction & $-0.471^{* *}$ \\
Communicating with English speakers & $-0.492^{* *}$ \\
Negative self-perception & $-0.380^{* *}$ \\
Noncomprehension & $-0.428^{* *}$ \\
Foreign language anxiety & $-0.613^{* *}$ \\
\hline
\end{tabular}

${ }^{* *}$ Correlation is significant at the 0.01 level (two-tailed). ${ }^{*}$ Correlation is significant at the 0.05 level (two-tailed). $N=242 ; r=$ Pearson's correlation.

Results of the correlation analysis revealed that there was a significant negative association between the overall foreign language anxiety and English proficiency $(r(242)=-0.613$, $p<0.01)$. All the different sources of language anxiety were significantly inversely correlated to English proficiency; however, the strength of the association varied, ranging from weak/ low $(r(242)=-0.38, p<0.01)$ to moderate $(r(242)=-0.675$, $p<0.01)$. This means that as the level of foreign language anxiety of the Filipino learners increases, their English proficiency performance lowers.

In order to determine how the variables influenced each other, a simple linear regression was calculated to predict English proficiency based on overall foreign language anxiety. A significant regression equation was found ( $F$ $(1,240)=144.14, p<0.001)$, with an $R^{2}$ of .375 . English proficiency is predicted as equal to $94.362+(-15.697)$, where English proficiency decreased by -15.697 points for each unit of overall foreign language anxiety increase.

A multiple regression model using the stepwise method was also calculated to determine the extent to which the sources of anxiety predict the respondents' English proficiency. An $F$ statistic of 200.857 with a $p$ value of $<0.001$ suggests that at least one of the variables of foreign language anxiety must be related to English proficiency. Further analysis revealed that, out of all the sources of anxiety, only speaking anxiety can significantly predict English proficiency. The fitted model shows that increasing anxiety by one unit will mean a 10.421 decrease in English proficiency score. The $R$ square of the model is .456 , meaning the model was able to account for $45.6 \%$ of the variance in the English proficiency scores. Fitting all the foreign language anxiety sources gives an $R$ square of .467 , which means that the variance explained is $46.7 \%$, a negligible difference of $1.1 \%$ from that of the model that has only speaking anxiety as a predictor. The model shows that English proficiency is equal to 78.909-10.421 times speaking activities anxiety. For every unit of increase in speaking activities anxiety of the Filipino learners, there is a decrease of 10.421 in their English proficiency score.

\subsection{Effects of Language Anxiety on the Second Language} Learning of the Undergraduate Filipino Teacher Education Learners. Table 13 presents the language process most affected by the foreign language anxiety of the respondents. These were based on the foreign language classroom
TABLE 13: Language process most affected by foreign language anxiety.

\begin{tabular}{lcc}
\hline Language process & $f$ & $\%$ \\
\hline Input & 36 & 9.40 \\
Process & 125 & 32.64 \\
Output & 246 & 64.23 \\
\hline
\end{tabular}

${ }^{*}$ Multiple response type; $n=242$.

situations described by the respondents as anxiety-causing. The majority of the answers given by the respondents ( 246 or $64.23 \%$ ) described classroom anxiety-causing situations categorized under the output stage, while most (125 or $32.64 \%$ ) are examples which are categorized under the process stage. Only $36(9.40 \%)$ of the answers can be categorized under the input stage.

There are three stages of language learning: the input stage, the process stage, and the output stage. The input stage is the first stage of language learning and involves receiving information from auditory and visual clues, while the process stage encompasses performing cognitive operations on new information. The output stage depends on the successful completion of the input and process stages [14]. When learners experience anxiety in the output stage, they suffer from nervousness or fear when required to demonstrate their linguistic ability using previously learned materials $[14,24]$. Filipino learners believe that the output stage of the language process is the most affected by language anxiety. What is common in the majority of the situations that they presented was the inability to perform various classroom tasks using the English language.

\section{Conclusions and Recommendations}

The results illustrate that the majority of the Filipino learners studied experienced an overall moderate level of English language anxiety and performed averagely in their English proficiency exam. Speaking activities are the primary source of high anxiety, followed by error correction and communicating with native English speakers, while writing activity, negative self-perception, and noncomprehension are all sources of moderate English language anxiety. The respondents also reported that the English language anxiety that individuals feel is anchored on one's self-perception.

Moreover, English language anxiety and English proficiency are significantly negatively correlated with each other. English language anxiety can predict English proficiency, with speaking activities anxiety as a significant predictor. This implies that a more anxious learner tended to have a lower English proficiency performance, and English language anxiety can be used to predict performance. This is reflected in their English language class, where the Filipino learners tend to experience anxiety more in situations involving the output process of language learning.

Thus, to improve the performance of learners in their English language class, language teachers need to be adequately equipped to observe when there is an excessive amount of anxiety attendant to language learning, which prevents students from functioning and from acting on these 
observations. It is then on this premise that language teachers have to address to gain optimum results on the teaching and learning of English as a second language. Teacher's classroom management strategy to control the anxiety of learners is essential. The strategies that the teachers will utilize must be suited to the sources and causes of anxiety experienced by the learners. Since speaking activities anxiety and communicating with native English speakers are identified sources of high anxiety for the learners, the teacher can give the students varied opportunities to practice speaking in English prior to requiring them to talk in classroom situations. Error correction is also a source of high anxiety; thus, instead of correcting a specific student, the teacher can opt to discuss the appropriate answer generally while addressing the entire class, therefore avoiding placing the spotlight on a particular learner and causing anxiety. In addition, previous studies have also suggested the following as effective strategies in handling learners with language anxiety: sharing language learning experiences and feelings, setting realistic and achievable goals, encouraging and praising learners often.

Although the context of this study is reflective of a typical EFL classroom setting and can be generalized to other EFL classes, particularly in Asia, other external variables might also affect the attributes of anxiety experienced by learners. A study using learners with different backgrounds is then recommended to understand better the level, sources, and causes of learner's English language anxiety and its relationship with English proficiency as well as how it affects language learning.

\section{Data Availability}

All relevant data were included in the manuscript. The corresponding author can be reached for the raw data.

\section{Conflicts of Interest}

The author declares no conflicts of interest regarding the publication of this article.

\section{References}

[1] F. M. Al-Khasawneh, "Investigating foreign language learning anxiety: a case of Saudi undergraduate EFL learners," Journal of Language and Linguistic Studies, vol. 12, no. 1, pp. 137-148, 2016.

[2] B. Teng and K. Sinwongsuwat, "Teaching and learning English in Thailand and the integration of Conversation Analysis (CA) into the classroom," English Language Teaching, vol. 8, no. 3, pp. 13-23, 2015.

[3] A. Al-Tamimi and M. Shuib, "The english language curriculum for petroleum engineering students at hadhramout university of science and technology," Higher Education in the Asia Pacific: Emerging Trends in Teaching and Learning, pp. 115-125, Penerbit Universiti Sains Malaysia, Gelugor, Malaysia, 2008.

[4] T. Tinsley and K. Board, Languages for the Future, The British Council, London, UK, 2013, https://www.britishcouncil.org/ sites/default/files/languages-for-the-future-report-v3.pdf.

[5] T. Tinsley and K. Board, Language Trends 2015/16: The State of Language Learning in Primary and Secondary Schools in
England, Education Development Trust, Reading, UK, 2016, https://www.britishcouncil.org/sites/default/files/language_ trends_survey_2016_0.pdf.

[6] Department of Education, "DO 52 S.. 1987, The 1987 policy on bilingual education," 1987, https://www.deped.gov.ph/1987/05/ 21/do-52-s-1987-the-1987-policy-on-bilingual-education/.

[7] English First, EF English Proficiency Index, Education First ltd, Lucerne, Switzerland, 2016.

[8] M. Liu and J. Jackson, "An exploration of Chinese EFL learners' unwillingness to communicate and foreign language anxiety," The Modern Language Journal, vol. 92, no. 1, pp. 71-86, 2008.

[9] L. Woodrow, "Anxiety and speaking as A second language," RELC Journal, vol. 37, no. 3, pp. 308-328, 2006.

[10] T. Scovel, "The effect of affect on foreign language learning: a review of the anxiety research," Language Learning: A Journal of Research in Language Studies, vol. 28, no. 1, pp. 129-142, 1978.

[11] E. K. Horwitz, M. B. Horwitz, and J. Cope, "foreign language classroom Anxiety," The Modern Language Journal, vol. 70, no. 2, pp. 125-132, 1986.

[12] P. D. MacIntyre and R. C. Gardner, "The effects of induced anxiety on three stages of cognitive processing in computerized vocabulary learning," Studies in Second Language Acquisition, vol. 16, pp. 1-17, 1993.

[13] R. Von Wörde, Students' Perspectives on Foreign Language Anxiety, Virginia Community College System, Richmond, VA, USA, 2003.

[14] M. Tanveer, "Investigation of the factors that cause language anxiety for esl/efl learners in learning speaking skills and the influence it casts on communication in the target language," in Doctoral Dissertation, University of Glasgow, Glasgow UK, 2007.

[15] Ö. Yalçın and V. İnceçay, "Foreign language speaking anxiety: the case of spontaneous speaking activities," Procedia-Social and Behavioral Sciences, vol. 116, pp. 2620-2624, 2014.

[16] D. J. Young, “An investigation of students' perspectives on anxiety and speaking," Foreign Language Annals, vol. 23, no. 6, pp. 539-553, 1990.

[17] M. Yahya, "Measuring speaking anxiety among speech communication course students at the Arab American University of Jenin (AAUJ)," European Social Sciences Journal, vol. 1, no. 3, 2013.

[18] U. Yayla, H. Ustaci, and S. Ok, "Preferences of ELT learners on the strategies used in the correction of oral grammar errors," International Journal of Business and Social Science, vol. 4, no. 8, pp. 244-254, 2013.

[19] M. Hashemi, "Language stress and anxiety among the english language learners," Procedia-Social and Behavioral Sciences, vol. 30, pp. 1811-1816, 2011.

[20] S. Matsuda and P. Gobel, "Anxiety and predictors of performance in the foreign language classroom," System, vol. 32, no. 1, pp. 21-36, 2004.

[21] C. E. Daley, P. Bailey, and A. J. Onwuegbuzie, "Foreign language anxiety and learning style," Foreign Language Annals, vol. 32, no. 1, pp. 63-76, 1999.

[22] M. A. Casado and M. I. Dereshiwsky, "Foreign language anxiety of university students," College Student Journal, vol. 35, no. 4, pp. 539-549, 2001.

[23] P. L. Carrell and W. Grabe, "Reading," An Introduction to Applied Linguistics, pp. 233-250, Edinburgh University Press, Edinburgh, UK, 2002.

[24] A. J. Onwuegbuzie, "Statistics anxiety and the role of selfperceptions," The Journal of Educational Research, vol. 93, no. 5 , pp. 323-330, 2000. 